\title{
Differential gene expression in response to Fusarium oxysporum infection in resistant and susceptible genotypes of flax (Linum usitatissimum L.)
}

\author{
Alexey A. Dmitriev ${ }^{1 \dagger}$, George S. Krasnov ${ }^{1 \dagger}$, Tatiana A. Rozhmina ${ }^{1,2}$, Roman O. Novakovskiy ${ }^{1}$, \\ Anastasiya V. Snezhkina', Maria S. Fedorova', Olga Yu. Yurkevich', Olga V. Muravenko', Nadezhda L. Bolsheva', \\ Anna V. Kudryavtseva ${ }^{1}$ and Nataliya V. Melnikova ${ }^{1 *}$
}

From Belyaev Conference

Novosibirsk, Russia. 07-10 August 2017

\begin{abstract}
Background: Flax (Linum usitatissimum L.) is a crop plant used for fiber and oil production. Although potentially high-yielding flax varieties have been developed, environmental stresses markedly decrease flax production. Among biotic stresses, Fusarium oxysporum f. sp. lini is recognized as one of the most devastating flax pathogens. It causes wilt disease that is one of the major limiting factors for flax production worldwide. Breeding and cultivation of flax varieties resistant to $F$. oxysporum is the most effective method for controlling wilt disease. Although the mechanisms of flax response to Fusarium have been actively studied, data on the plant response to infection and resistance gene candidates are currently very limited.
\end{abstract}

Results: The transcriptomes of two resistant and two susceptible flax cultivars with respect to Fusarium wilt, as well as two resistant $\mathrm{BC}_{2} \mathrm{~F}_{5}$ populations, which were grown under control conditions or inoculated with $F$. oxysporum, were sequenced using the Illumina platform. Genes showing changes in expression under F. oxysporum infection were identified in both resistant and susceptible flax genotypes. We observed the predominant overexpression of numerous genes that are involved in defense response. This was more pronounced in resistant cultivars. In susceptible cultivars, significant downregulation of genes involved in cell wall organization or biogenesis was observed in response to $F$. oxysporum. In the resistant genotypes, upregulation of genes related to $\mathrm{NAD}(\mathrm{P}) \mathrm{H}$ oxidase activity was detected. Upregulation of a number of genes, including that encoding beta-1,3-glucanase, was significantly greater in the cultivars and $\mathrm{BC}_{2} \mathrm{~F}_{5}$ populations resistant to Fusarium wilt than in susceptible cultivars in response to $F$. oxysporum infection.

\footnotetext{
* Correspondence: mnv-4529264@yandex.ru

${ }^{\dagger}$ Equal contributors

${ }^{1}$ Engelhardt Institute of Molecular Biology, Russian Academy of Sciences,

Moscow, Russia

Full list of author information is available at the end of the article
} 
(Continued from previous page)

Conclusions: Using high-throughput sequencing, we identified genes involved in the early defense response of $L$. usitatissimum against the fungus F. oxysporum. In response to F. oxysporum infection, we detected changes in the expression of pathogenesis-related protein-encoding genes and genes involved in ROS production or related to cell wall biogenesis. Furthermore, we identified genes that were upregulated specifically in flax genotypes resistant to Fusarium wilt. We suggest that the identified genes in resistant cultivars and $\mathrm{BC}_{2} \mathrm{~F}_{5}$ populations showing induced expression in response to F. oxysporum infection are the most promising resistance gene candidates.

Keywords: Linum usitatissimum, Flax, Biotic stress, Fusarium oxysporum, High-throughput sequencing, ROS, 1,3-betaglucanase, Cell wall,

\section{Background}

Flax (Linum usitatissimum L.) is a widely distributed crop, which is used for fiber and oil production [1]. Genetic polymorphism of L. usitatissimum and related species is well characterized [2-7] and could be used for the breeding of improved cultivars. Although potentially highyielding flax varieties have previously been developed, biotic and abiotic stresses can markedly decrease flax production. Therefore, the molecular mechanisms underlying the responses of flax to unfavorable environments are intensively studied. In this regard, changes in the expression of stress-responsive genes and microRNAs have been detected in flax plants under abiotic stresses, such as drought [8], salinity and alkalinity $[9,10]$, nutrient imbalance [11], and high concentrations of aluminum ions [12,13].

Among biotic stresses, Fusarium oxysporum f. sp. lini is recognized as one of the most devastating flax pathogen. It causes wilt disease, which is one of the major limiting factors for flax production in most of the flaxgrowing areas worldwide. Epidemics of the disease can result in an $80 \%$ to $100 \%$ loss in yield [14]. Breeding and cultivation of flax varieties resistant to $F$. oxysporum is the most effective method for controlling wilt disease, and in this regard, evaluation of flax germplasm for resistance to Fusarium wilt has revealed accessions with potential utility in breeding programs [15]. Furthermore, the search for genes conferring resistance to Fusarium infection is currently underway, and amplified fragment length polymorphism (AFLP) analysis of a flax mapping population derived from doubled haploid lines has already led to the identification of two quantitative trait loci associated with resistance to Fusarium wilt [16]. However, the genes that define resistance to Fusarium in some flax genotypes remain unknown.

Alterations that occur in flax plants under Fusarium infection have been actively studied and, in some cases, the molecular mechanisms underlying responses have been elucidated. The role of pathogenesis-related (PR) proteins, including chitinase and $\beta$-1,3-glucanase, in response to Fusarium has been revealed. Upregulation of chitinase genes has been identified in flax plants under F. oxysporum infection [17]. Flax lines with ectopic expression of the $\beta$-1,3-glucanase gene or overexpression of endogenous $\beta$-1,3-glucanase gene show enhanced resistance to $F$. oxysporum and $F$. culmorum $[18,19]$. Moreover, those flax plants with overexpressed $\beta-1,3-$ glucanase have increased contents of antioxidants, phenolics, and polyamines, as well as alterations in cell wall biopolymer composition [18-20]. Enhanced resistance via an increase in antioxidant activity has also been observed in transgenic flax plants with increased contents of flavonoids, carotenoids, or other terpenoids [21-23]. Furthermore, the involvement of antioxidants and cell wall components in the flax response to Fusarium has been demonstrated in different plant material, including cell cultures, seeds, and seedlings. Oxidative burst, activation of lipid peroxidation, and phenylpropanoid metabolism have been observed in flax cells under interaction with F. oxysporum [24]. The contribution of the antioxidant potential of phenylpropanoids, which accumulate in seeds, and pectin content in flax resistance to Fusarium have also been identified [25], as have the changes in pectin metabolism in flax seedlings under $\mathrm{Fu}$ sarium infection [26]. Changes in the expression of genes participating in stress response, defense response, metabolism regulation, and, in particular, the phenylpropanoid pathway have been detected in flax plants during the early stages of Fusarium infection [27], and it has been suggested that an increase in methyl salicylate level in flax plants in response to $F$. oxysporum is associated with activation of the phenylpropanoid pathway [28]. The role of polyamines in response to Fusarium has also been revealed [29]. RNA-seq of flax plants after infection with $F$. oxysporum allowed identification of changes in the expression of genes involved in signal transduction, regulation of transcription, hormone signaling, reactive oxygen species (ROS) regulation, secondary metabolism, and other processes [17]. Thus, it has been variously established that PR-proteins, antioxidants, and cell wall components are involved in the flax response to Fusarium infection.

In the present study, we used high-throughput sequencing of transcriptomes to evaluate the changes in flax gene expression under $F$. oxysporum infection in resistant and susceptible flax cultivars and $\mathrm{BC}_{2} \mathrm{~F}_{5}$ populations, the latter 
of which were obtained from crosses between resistant and susceptible flax cultivars and then selected for both resistance to F. oxysporum and phenotypical similarity with the susceptible parent for several generations. This approach allowed us to identify candidate genes conferring resistance to F. oxysporum infection in L. usitatissimum.

\section{Methods}

\section{Plant material}

Experiments for identification of flax cultivars with resistance and susceptibility to $F$. oxysporum have previously been performed at the All-Russian Research Institute for Flax (Torzhok, Russia). Based on the obtained results, two resistant (Dakota and \#3896) and two susceptible (AP5 and TOST) cultivars were selected for examination in the present study. In addition, hybrids of cultivars resistant and susceptible to $F$. oxysporum were obtained at the same institute. The susceptible cultivar AP5 was crossed with both resistant cultivars (Dakota and \#3896), and the resulting $F_{1}$ plants were backcrossed to AP5. Subsequently, selection against a provocative background (soil inoculated with an isolate of Fusarium oxysporum f. sp. lini) was performed and plants that were resistant but phenotypically similar to the AP5 cultivar were selected. A further backcross was then conducted and resistant plants similar to AP5 were again selected. Thereafter, self-pollination of $\mathrm{BC}_{2} \mathrm{~F}_{1}$ individuals and selection of resistant families that were phenotypically similar to AP5 were performed for five generations. As a result, $\mathrm{BC}_{2} \mathrm{~F}_{5}$ populations resistant to $F$. oxysporum were obtained: \#3896 × AP5 (recurrent parent AP5) and Dakota $\times$ AP5 (recurrent parent AP5).

Thus, two cultivars with resistance (Dakota and \#3896) and two cultivars with susceptibility (AP5 and TOST) to $F$. oxysporum, as well as resistant $\mathrm{BC}_{2} \mathrm{~F}_{5}$ populations (\#3896 $\times$ AP5 and Dakota $\times$ AP5), were used in our study. Seeds were initially sterilized in $70 \%$ ethanol for $1 \mathrm{~min}$ and in $1 \%$ sodium hypochlorite for $20 \mathrm{~min}$, and then rinsed 15 times in sterile deionized water. The plants were grown in sterile $16 \mathrm{~mm} \times 150 \mathrm{~mm}$ glass tubes on Murashige-Skoog medium in a growth chamber at $22{ }^{\circ} \mathrm{C}$ with a $16 \mathrm{~h}$ day and $8 \mathrm{~h}$ night.

Fusarium oxysporum f. sp. lini pathogenic isolate \#39 from the phytopathogen collection of the All-Russian Research Institute for Flax was grown on potato dextrose agar for 5 days prior to inoculation. This was the same isolate that was applied for selection of resistant families after crosses between Dakota and AP5 and \#3896 and AP5. Seven-day-old flax plants were inoculated with $1 \mathrm{ml}$ of a $10^{5}$ per $\mathrm{ml}$ preparation of $F$. oxysporum spores (fungal infection) or with $1 \mathrm{ml}$ of sterile water (control). After $48 \mathrm{~h}$, when necrosis of roots had appeared, root tips (approx. $5 \mathrm{~mm}$ in length), in which the infection initially occurred, were collected and frozen in liquid nitrogen. It was previously shown that $F$. oxysporum displays a clear preference for the root tips of flax. Two days after inoculation, the fungus was mainly distributed around the root tips, with significantly less presence in the elongation zone and in lateral branches [30]. Accordingly, for studying the early infection stages, we selected root tips as the most preferable experimental material. In total, approximately 120 infected plants and 120 plants grown under control conditions were obtained for four cultivars and two $\mathrm{BC}_{2} \mathrm{~F}_{5}$ populations.

\section{Library preparation and transcriptome sequencing}

Total RNA was extracted from pooled plant samples using an RNeasy Plant Mini Kit (Qiagen, USA). Each pool included 10-12 plants of each cultivar/population under control conditions or fungal infection. Thus, 24 RNA samples were extracted in two replicates under either fungal infection or control conditions: Dakota, \#3896, AP5, TOST, $\mathrm{BC}_{2} \mathrm{~F}_{5} \# 3896 \times \mathrm{AP5}$, and $\mathrm{BC}_{2} \mathrm{~F}_{5}$ Dakota $\times \mathrm{AP5}$. RNA concentration and quality were evaluated using a Qubit 2.0 fluorometer (Life Technologies, USA) and Agilent 2100 Bioanalyzer (Agilent Technologies, USA). Highquality RNA samples (RNA integrity number not less than 8.0) were used for cDNA library preparation with polyAbased mRNA capture using a TruSeq Stranded Total RNA Library Prep Kit (Illumina, USA). The quality of the 24 obtained libraries was evaluated using the Agilent 2100 Bioanalyzer. The libraries were sequenced using a NextSeq 500 high-throughput sequencer (Illumina) and paired-end reads ( $80+80$ nucleotides) were obtained.

\section{High-throughput sequencing data analysis}

Illumina reads were trimmed and filtered using Trimmomatic [31] and then $F$. oxysporum reads were filtered out by mapping to the $F$. oxysporum reference genome and transcriptome (NCBI assembly/WGS identifier ASM14995v2/ AAXH01) using bowtie2. The remaining reads were used for transcriptome assembly using Trinity 2.4 .0 with the default parameters [32]. The assembly was performed (1) for each cultivar/population, (2) for each $\mathrm{BC}_{2} \mathrm{~F}_{5}$ population jointly with the corresponding parents, and (3) for all sequenced flax samples together.

The quality of assemblies was assessed with N50, ExN50, and L50 statistics using QUAST 4.5 and Trinity utilities. Trasncripts that were less than 200 nucleotides in length were excluded from subsequent analysis. The transcripts were also analyzed with BUSCO to evaluate the completeness of the assembly [33]. Trinotate pipeline was then used for the annotation of the assembled transcripts (http://trinotate.github.io/). The derived transcripts were analyzed for the presence of open reading frames (ORFs) using TransDecoder [34]. The transcripts and the predicted proteins were aligned to the UniProt database using blastx and blastp, respectively. The protein sequences 
Table 1 Transcriptome assembly statistics for flax cultivars and $\mathrm{BC}_{2} \mathrm{~F}_{5}$ populations

\begin{tabular}{|c|c|c|c|c|c|c|c|c|c|}
\hline Feature & AP5 & TOST & Dakota & $\# 3896$ & Dakota $\times$ AP5 & $\# 3896 \times$ AP5 & Dakota $\times$ AP5, Dakota, AP5 & $\# 3896 \times$ AP5, \#3896,AP5 & All samples \\
\hline Genes & 52,659 & 52,802 & 52,287 & 55,062 & 51,758 & 52,088 & 72,128 & 73,473 & 89,290 \\
\hline Transcripts & 110,764 & 108,737 & 107,255 & 111,051 & 108,107 & 109,009 & 151,218 & 154,343 & 183,905 \\
\hline GC-content & 46 & 46 & 46 & 46 & 46 & 46 & 46 & 46 & 46 \\
\hline N50 & 1776 & 1804 & 1806 & 1810 & 1810 & 1831 & 1874 & 1859 & 1882 \\
\hline $\begin{array}{l}\text { Median } \\
\text { contig length }\end{array}$ & 998 & 1000 & 1010 & 987 & 1015 & 1032 & 997 & 987 & 923 \\
\hline $\begin{array}{l}\text { Average } \\
\text { contig length }\end{array}$ & 1212 & 1220 & 1225 & 1214 & 1228 & 1245 & 1247 & 1235 & 1216 \\
\hline $\begin{array}{l}\text { Total } \\
\text { assembled } \\
\text { bases, Mb }\end{array}$ & 134.2 & 132.7 & 131.3 & 134.8 & 132.7 & 135.8 & 188.5 & 190.7 & 223.7 \\
\hline
\end{tabular}

were scanned for the presence of PFAM domains using HMMER [35, 36]. On the basis of these data, a local SQLite database was constructed and transferred to Trinotate. Finally, the transcripts were annotated using the Gene Ontology (GO), KEGG, and COG databases.

Then reads were mapped to the assembled transcripts (all nine assemblies) and quantified using bowtie2 [37] and rsem [38]. Read counts per transcript and per gene were calculated. The derived read count data were analyzed using edgeR [39]. After normalization using the TMM method, we attempted to identify the following gene responses:

1. up- and down-regulated in flax genotypes resistant to F. oxysporum (Dakota, \#3896, \#3896 × AP5, Dakota $\times$ AP5) in response to $F$. oxysporum infection;
2. up- and down-regulated in flax genotypes susceptible to F. oxysporum (AP5 and TOST) in response to $F$. oxysporum infection;

3 . induced in response to F. oxysporum infection in the resistant cultivars and $\mathrm{BC}_{2} \mathrm{~F}_{5}$ populations, but not (or less so) in the susceptible cultivars.

Only genes with a CPM greater than 2.0 for at least three samples were used for further analysis. The $t$-test was used to determine $p$-values. False discovery rate (FDR) values were derived using the Benjamini-Hochberg p-value adjustment procedure. The gene set enrichment analysis (GSEA) with GO data was performed using Goseq [40]. For this analysis, we used lists of the top 50, $100,200,500,1000$, and 2000 upregulated or downregulated genes, separately. Different GO terms were enriched

Table 2 Gene ontology analysis for the top 100 upregulated genes in flax genotypes resistant to Fusarium oxysporum (Dakota, \#3896, \#3896 × AP5, and Dakota × AP5)

\begin{tabular}{|c|c|c|c|c|c|}
\hline $\begin{array}{l}\mathrm{GO} \\
\text { category }\end{array}$ & Term & Observed number of genes & Expected number of genes & $p$-value & $F D R$ \\
\hline GO:0008137 & NADH dehydrogenase (ubiquinone) activity & 6 & 0.15 & $1.5 \mathrm{E}-08$ & $1.1 \mathrm{E}-04$ \\
\hline GO:0050136 & NADH dehydrogenase (quinone) activity & 6 & 0.15 & $1.5 \mathrm{E}-08$ & 1.1E-04 \\
\hline GO:0003954 & NADH dehydrogenase activity & 6 & 0.17 & 3.3E-08 & 1.7E-04 \\
\hline GO:1,990,204 & oxidoreductase complex & 7 & 0.38 & $5.0 \mathrm{E}-08$ & 1.9E-04 \\
\hline GO:0005747 & mitochondrial respiratory chain complex I & 5 & 0.14 & $1.2 \mathrm{E}-07$ & $2.8 \mathrm{E}-04$ \\
\hline GO:0045271 & respiratory chain complex I & 5 & 0.14 & $1.2 \mathrm{E}-07$ & $2.8 \mathrm{E}-04$ \\
\hline GO:0030964 & NADH dehydrogenase complex & 5 & 0.14 & $1.4 \mathrm{E}-07$ & $2.8 \mathrm{E}-04$ \\
\hline GO:0016655 & $\begin{array}{l}\text { oxidoreductase activity, acting on } \mathrm{NAD}(\mathrm{P}) \mathrm{H} \text {, } \\
\text { quinone or similar compound as acceptor }\end{array}$ & 6 & 0.23 & $1.5 \mathrm{E}-07$ & $2.8 \mathrm{E}-04$ \\
\hline GO:0044455 & mitochondrial membrane part & 8 & 0.61 & $2.0 \mathrm{E}-07$ & $3.4 \mathrm{E}-04$ \\
\hline GO:0044429 & mitochondrial part & 14 & 2.58 & 4.0E-07 & $6.2 \mathrm{E}-04$ \\
\hline GO:0016651 & oxidoreductase activity, acting on $\mathrm{NAD}(\mathrm{P}) \mathrm{H}$ & 7 & 0.56 & $1.5 \mathrm{E}-06$ & $2.1 \mathrm{E}-03$ \\
\hline GO:0009435 & NAD biosynthetic process & 3 & 0.04 & $2.8 \mathrm{E}-05$ & $3.6 \mathrm{E}-02$ \\
\hline $\mathrm{GO}: 1,901,566$ & organonitrogen compound biosynthetic process & 12 & 2.93 & 4.4E-05 & $5.3 \mathrm{E}-02$ \\
\hline
\end{tabular}


Table 3 Gene ontology analysis for the top 100 upregulated genes in the flax genotypes susceptible to Fusarium oxysporum (AP5 and TOST)

\begin{tabular}{|c|c|c|c|c|c|}
\hline $\begin{array}{l}\mathrm{GO} \\
\text { category }\end{array}$ & Term & Observed number of genes & Expected number of genes & $p$-value & $F D R$ \\
\hline GO:0002181 & cytoplasmic translation & 12 & 0.24 & 0 & 0 \\
\hline GO:0003735 & structural constituent of ribosome & 30 & 1.61 & $1.6 \mathrm{E}-32$ & $1.3 \mathrm{E}-28$ \\
\hline GO:0006412 & translation & 29 & 1.87 & $1.9 \mathrm{E}-28$ & $9.8 \mathrm{E}-25$ \\
\hline GO:0005198 & structural molecule activity & 30 & 2.30 & $1.3 \mathrm{E}-27$ & $5.0 \mathrm{E}-24$ \\
\hline GO:0044391 & ribosomal subunit & 21 & 1.08 & $8.8 \mathrm{E}-23$ & 2.7E-19 \\
\hline GO:0030529 & intracellular ribonucleoprotein complex & 34 & 4.47 & $1.8 \mathrm{E}-22$ & 4.7E-19 \\
\hline GO:0044445 & cytosolic part & 21 & 1.26 & $2.4 \mathrm{E}-21$ & $5.3 \mathrm{E}-18$ \\
\hline GO:0022625 & cytosolic large ribosomal subunit & 14 & 0.46 & $1.5 \mathrm{E}-18$ & $2.8 \mathrm{E}-15$ \\
\hline GO:0015934 & large ribosomal subunit & 14 & 0.61 & $2.3 \mathrm{E}-16$ & $3.9 \mathrm{E}-13$ \\
\hline GO:0009059 & macromolecule biosynthetic process & 41 & 11.92 & $5.1 \mathrm{E}-14$ & $8.0 \mathrm{E}-11$ \\
\hline GO:0034645 & cellular macromolecule biosynthetic process & 39 & 11.27 & $2.2 \mathrm{E}-13$ & $3.1 \mathrm{E}-10$ \\
\hline $\mathrm{GO}: 1,901,576$ & organic substance biosynthetic process & 49 & 19.57 & $4.9 \mathrm{E}-12$ & $6.3 \mathrm{E}-09$ \\
\hline GO:0009058 & biosynthetic process & 49 & 20.57 & $3.0 \mathrm{E}-11$ & 3.6E-08 \\
\hline GO:0044249 & cellular biosynthetic process & 47 & 19.05 & $3.9 \mathrm{E}-11$ & $4.4 \mathrm{E}-08$ \\
\hline GO:0032991 & macromolecular complex & 41 & 15.18 & 2.4E-10 & $2.5 \mathrm{E}-07$ \\
\hline GO:0022627 & cytosolic small ribosomal subunit & 7 & 0.32 & $5.9 \mathrm{E}-09$ & 5.7E-06 \\
\hline GO:0005840 & ribosome & 11 & 1.28 & $1.1 \mathrm{E}-08$ & $1.0 \mathrm{E}-05$ \\
\hline GO:0044267 & cellular protein metabolic process & 29 & 9.71 & $4.8 \mathrm{E}-08$ & 4.2E-05 \\
\hline GO:0015935 & small ribosomal subunit & 7 & 0.47 & $2.0 \mathrm{E}-07$ & $1.6 \mathrm{E}-04$ \\
\hline GO:0019538 & protein metabolic process & 30 & 11.46 & $5.0 \mathrm{E}-07$ & $3.9 \mathrm{E}-04$ \\
\hline GO:0006414 & translational elongation & 4 & 0.07 & $8.9 \mathrm{E}-07$ & $6.6 \mathrm{E}-04$ \\
\hline GO:0045460 & sterigmatocystin metabolic process & 4 & 0.13 & $1.2 \mathrm{E}-05$ & $8.2 \mathrm{E}-03$ \\
\hline GO:0045461 & sterigmatocystin biosynthetic process & 4 & 0.13 & $1.2 \mathrm{E}-05$ & $8.2 \mathrm{E}-03$ \\
\hline GO:1,901,378 & $\begin{array}{l}\text { organic heteropentacyclic compound } \\
\text { biosynthetic process }\end{array}$ & 4 & 0.18 & $3.5 \mathrm{E}-05$ & $2.3 \mathrm{E}-02$ \\
\hline GO:1,901,376 & $\begin{array}{l}\text { organic heteropentacyclic compound } \\
\text { metabolic process }\end{array}$ & 4 & 0.18 & 3.7E-05 & $2.3 \mathrm{E}-02$ \\
\hline GO:0009403 & toxin biosynthetic process & 4 & 0.21 & $6.6 \mathrm{E}-05$ & $3.9 \mathrm{E}-02$ \\
\hline GO:0070069 & cytochrome complex & 3 & 0.10 & $6.8 \mathrm{E}-05$ & $3.9 \mathrm{E}-02$ \\
\hline
\end{tabular}

Note: One gene can belong to several GO categories. FDR - false discovery rate

when we used distinct top differentially expressed gene list sizes.

\section{Results}

\section{High-throughput sequencing of flax plants}

We sequenced the transcriptomes of flax cultivars showing resistance (Dakota and \#3896) and susceptibility (AP5 and TOST) to Fusarium wilt, which were exposed to control conditions or inoculated with $F$. oxysporum. We also sequenced the transcriptomes of $\mathrm{BC}_{2} \mathrm{~F}_{5}$ populations $(\# 3896 \times \mathrm{AP} 5$, recurrent parent AP5; Dakota $\times$ AP5, recurrent parent AP5) with resistance to $F$. oxysporum. From 45.7 to 55.7 million reads were generated for each cultivar or $\mathrm{BC}_{2} \mathrm{~F}_{5}$ population under control conditions or F. oxysporum infection. For plants inoculated with pathogen samples, $30 \%-46 \%$ of reads were mapped to the $F$. oxysporum genome and transcriptome. In control plants, less than $0.2 \%$ of reads were mapped to the $F$. oxysporum sequences (the most of these reads were rRNA-originated), which can be explained by the similarity of some flax and Fusarium sequences. After filtering against the $F$. oxysporum genome and transcriptome, the following transcriptome assemblies were performed: (1) for each cultivar and $\mathrm{BC}_{2} \mathrm{~F}_{5}$ population separately; (2) for each $\mathrm{BC}_{2} \mathrm{~F}_{5}$ population jointly with the corresponding parents; (3) for all cultivars and $\mathrm{BC}_{2} \mathrm{~F}_{5}$ populations together. Approximately 
Table 4 Gene ontology analysis for the top 100 downregulated genes in the flax genotypes resistant to Fusarium oxysporum (Dakota, \#3896, \#3896 × AP5, Dakota × AP5)

\begin{tabular}{|c|c|c|c|c|c|}
\hline $\begin{array}{l}\mathrm{GO} \\
\text { category }\end{array}$ & Term & Observed number of genes & Expected number of genes & $p$-value & $F D R$ \\
\hline GO:0003777 & microtubule motor activity & 10 & 0.35 & 0 & 0 \\
\hline GO:0007018 & microtubule-based movement & 11 & 0.40 & 0 & 0 \\
\hline GO:0007017 & microtubule-based process & 15 & 1.15 & $1.2 \mathrm{E}-12$ & $5.5 \mathrm{E}-09$ \\
\hline GO:0005874 & microtubule & 15 & 1.16 & $1.4 \mathrm{E}-12$ & $5.5 \mathrm{E}-09$ \\
\hline GO:0005871 & kinesin complex & 9 & 0.30 & $4.8 \mathrm{E}-11$ & $1.3 \mathrm{E}-07$ \\
\hline GO:0006928 & $\begin{array}{l}\text { movement of cell or subcellular } \\
\text { component }\end{array}$ & 11 & 0.60 & $5.0 \mathrm{E}-11$ & $1.3 \mathrm{E}-07$ \\
\hline GO:0003774 & motor activity & 10 & 0.48 & $1.8 \mathrm{E}-10$ & 4.0E-07 \\
\hline GO:0005875 & microtubule associated complex & 9 & 0.50 & $5.4 \mathrm{E}-09$ & 1.1 E-05 \\
\hline GO:0009524 & phragmoplast & 8 & 0.42 & $1.8 \mathrm{E}-08$ & $3.1 \mathrm{E}-05$ \\
\hline GO:0044430 & cytoskeletal part & 15 & 2.42 & $6.7 \mathrm{E}-08$ & $1.0 \mathrm{E}-04$ \\
\hline GO:0008574 & $\begin{array}{l}\text { ATP-dependent microtubule motor } \\
\text { activity, plus-end-directed }\end{array}$ & 4 & 0.06 & $4.4 \mathrm{E}-07$ & $6.2 \mathrm{E}-04$ \\
\hline GO:0000911 & cytokinesis by cell plate formation & 5 & 0.15 & $9.5 \mathrm{E}-07$ & $1.2 \mathrm{E}-03$ \\
\hline GO:0009506 & plasmodesma & 13 & 3.14 & $6.2 \mathrm{E}-06$ & 7.4E-03 \\
\hline GO:0005911 & cell-cell junction & 13 & 3.24 & $9.2 \mathrm{E}-06$ & $1.0 \mathrm{E}-02$ \\
\hline GO:0030130 & $\begin{array}{l}\text { clathrin coat of trans-Golgi network } \\
\text { vesicle }\end{array}$ & 3 & 0.06 & $9.8 \mathrm{E}-06$ & $1.0 \mathrm{E}-02$ \\
\hline GO:0030054 & cell junction & 13 & 3.36 & $1.5 \mathrm{E}-05$ & $1.4 \mathrm{E}-02$ \\
\hline GO:0030132 & clathrin coat of coated pit & 3 & 0.06 & 1.7E-05 & $1.5 \mathrm{E}-02$ \\
\hline GO:0030125 & clathrin vesicle coat & 3 & 0.07 & $2.8 \mathrm{E}-05$ & $2.4 \mathrm{E}-02$ \\
\hline GO:0030118 & clathrin coat & 3 & 0.08 & $4.9 \mathrm{E}-05$ & $4.0 \mathrm{E}-02$ \\
\hline GO:0005524 & ATP binding & 28 & 13.51 & $5.9 \mathrm{E}-05$ & 4.3E-02 \\
\hline GO:0061640 & cytoskeleton-dependent cytokinesis & 4 & 0.18 & $5.9 \mathrm{E}-05$ & 4.3E-02 \\
\hline GO:0032549 & ribonucleoside binding & 30 & 15.15 & $6.5 \mathrm{E}-05$ & 4.3E-02 \\
\hline GO:1,902,410 & mitotic cytokinetic process & 5 & 0.35 & $6.6 \mathrm{E}-05$ & 4.3E-02 \\
\hline GO:0001882 & nucleoside binding & 30 & 15.17 & $6.6 \mathrm{E}-05$ & 4.3E-02 \\
\hline GO:0032559 & adenyl ribonucleotide binding & 28 & 13.66 & 7.1E-05 & 4.4E-02 \\
\hline GO:0030554 & adenyl nucleotide binding & 28 & 13.68 & 7.3E-05 & 4.4E-02 \\
\hline
\end{tabular}

Note: One gene can belong to more than one GO category. FDR - false discovery rate

107-111 thousand transcripts related to 52-55 thousand genes were derived for each cultivar and $\mathrm{BC}_{2} \mathrm{~F}_{5}$ population. For the $\mathrm{BC}_{2} \mathrm{~F}_{5}$ population combined with the corresponding parents and for all analyzed samples, a larger number of genes and transcripts were identified (Table 1). In the annotation of transcripts, approximately $50 \%$ of the transcripts were successfully mapped to UniProt using blastx. For almost $60 \%$ of the transcripts, long ORFs were identified. Approximately 23,000 transcripts passed the CPM threshold and were used for differential expression analysis. To assess the completeness of transcriptome assemblies, we mapped the transcripts to the database of singlecopy orthologs among Embryophyta with BUSCO. The assembly that was derived with the complete pool of reads (all samples), as well as the assemblies that included either susceptible or resistant cultivars and populations demonstrated equally good completeness: $91 \%-92 \%$ of complete orthologs were present. The assemblies that included only one cultivar/population revealed slightly lower values $(85 \%-88 \%)$.

\section{Changes in gene expression in flax plants under $F$. Oxysporum infection}

Expression analysis was performed for identification of up- and down-regulated genes under F. oxysporum infection. Expression levels of identified transcripts were evaluated for all received assemblies under control conditions and at $48 \mathrm{~h}$ post-inoculation in the following groups: (1) separately for each of the studied cultivars and $\mathrm{BC}_{2} \mathrm{~F}_{5}$ populations; (2) pool of cultivars resistant (Dakota and \#3896) and pool of cultivars susceptible 
Table 5 Gene ontology analysis for the top 100 downregulated genes in the flax genotypes susceptible to Fusarium oxysporum (AP5 and TOST)

\begin{tabular}{|c|c|c|c|c|c|}
\hline $\begin{array}{l}\mathrm{GO} \\
\text { category }\end{array}$ & Term & Observed number of genes & Expected number of genes & p-value & $F D R$ \\
\hline GO:0071555 & cell wall organization & 21 & 2.32 & $4.6 \mathrm{E}-15$ & $7.1 \mathrm{E}-11$ \\
\hline GO:0071554 & cell wall organization or biogenesis & 22 & 2.78 & $1.8 \mathrm{E}-14$ & 1.0E-10 \\
\hline GO:0045229 & external encapsulating structure organization & 21 & 2.52 & $1.9 \mathrm{E}-14$ & $1.0 \mathrm{E}-10$ \\
\hline GO:0005576 & extracellular region & 26 & 5.10 & $6.7 \mathrm{E}-13$ & 2.6E-09 \\
\hline GO:0005618 & cell wall & 15 & 2.89 & $6.5 \mathrm{E}-08$ & 1.7E-04 \\
\hline GO:0030312 & external encapsulating structure & 15 & 2.89 & $6.5 \mathrm{E}-08$ & 1.7E-04 \\
\hline GO:0048046 & apoplast & 11 & 1.53 & $1.1 \mathrm{E}-07$ & $2.4 \mathrm{E}-04$ \\
\hline GO:0016762 & xyloglucan:xyloglucosyl transferase activity & 4 & 0.12 & $3.2 \mathrm{E}-06$ & $5.1 \mathrm{E}-03$ \\
\hline GO:0031225 & anchored component of membrane & 8 & 0.89 & $3.5 \mathrm{E}-06$ & $5.1 \mathrm{E}-03$ \\
\hline GO:0016757 & transferase activity, transferring glycosyl groups & 13 & 2.81 & 3.7E-06 & $5.1 \mathrm{E}-03$ \\
\hline GO:0005976 & polysaccharide metabolic process & 12 & 2.53 & $3.9 \mathrm{E}-06$ & $5.1 \mathrm{E}-03$ \\
\hline GO:0042546 & cell wall biogenesis & 7 & 0.72 & 4.3E-06 & $5.1 \mathrm{E}-03$ \\
\hline GO:0005372 & water transmembrane transporter activity & 4 & 0.16 & 4.5E-06 & $5.1 \mathrm{E}-03$ \\
\hline GO:0015250 & water channel activity & 4 & 0.16 & $4.5 \mathrm{E}-06$ & $5.1 \mathrm{E}-03$ \\
\hline GO:0031226 & intrinsic component of plasma membrane & 10 & 1.82 & $1.0 \mathrm{E}-05$ & $1.1 \mathrm{E}-02$ \\
\hline GO:0031224 & intrinsic component of membrane & 39 & 20.87 & $1.8 \mathrm{E}-05$ & 1.7E-02 \\
\hline GO:0046658 & anchored component of plasma membrane & 6 & 0.57 & $2.5 \mathrm{E}-05$ & 2.3E-02 \\
\hline GO:0005975 & carbohydrate metabolic process & 18 & 6.30 & $2.9 \mathrm{E}-05$ & $2.5 \mathrm{E}-02$ \\
\hline GO:0004553 & $\begin{array}{l}\text { hydrolase activity, hydrolyzing O-glycosyl } \\
\text { compounds }\end{array}$ & 10 & 2.12 & 3.8E-05 & 3.1E-02 \\
\hline GO:0009505 & plant-type cell wall & 7 & 1.05 & $4.9 \mathrm{E}-05$ & 3.7E-02 \\
\hline GO:0010411 & xyloglucan metabolic process & 4 & 0.22 & $4.9 \mathrm{E}-05$ & 3.7E-02 \\
\hline GO:0030570 & pectate lyase activity & 3 & 0.09 & $6.9 \mathrm{E}-05$ & 4.7E-02 \\
\hline GO:0016798 & hydrolase activity, acting on glycosyl bonds & 10 & 2.29 & 7.0E-05 & 4.7E-02 \\
\hline
\end{tabular}

(AP5 and TOST) to Fusarium wilt; (3) pools of resistant cultivars and derived $\mathrm{BC}_{2} \mathrm{~F}_{5}$ populations (Dakota and Dakota $\times$ AP5; \#3896 and \#3896 $\times$ AP5); (4) pool of resistant cultivars and $\mathrm{BC}_{2} \mathrm{~F}_{5}$ populations (Dakota, \#3896, Dakota $\times$ AP5, and \#3896 $\times$ AP5). For all assembly variants, the top differentially expressed genes were mostly similar. Further, the results of expression analysis for the assembly from all samples are presented.

Genes showing changes in expression under $F$. oxysporum infection were identified in both resistant and susceptible flax genotypes. GO analysis was performed for the top 100 up- and down-regulated genes. In the flax genotypes with resistance to $F$. oxysporum (resistant cultivars and $\mathrm{BC}_{2} \mathrm{~F}_{5}$ populations), the top 100 upregulated genes were related to $\mathrm{NAD}(\mathrm{P}) \mathrm{H}$ dehydrogenase activity, oxidoreductase activity, respiratory chain complex I, and mitochondrial parts (Table 2). In the susceptible cultivars, the top 100 upregulated genes were related to other categories, including translation, ribosome, biosynthetic process, and cytosolic part (Table 3). GO analysis of the top 100 downregulated genes also revealed differences between resistant and susceptible genotypes: in resistant genotypes, the genes were related to microtubule, kinesin complex, cytoskeletal part, cell junction, clathrin coat, and adenyl nucleotide binding (Table 4); in susceptible genotypes, the genes were related to cell wall, external encapsulating structure, transferase activity, transferring glycosyl groups, polysaccharide metabolic process, water channel activity, intrinsic component of membrane, and xyloglucan metabolic process (Table 5).

\section{Genes specifically upregulated in resistant genotypes of flax in response to $F$. Oxysporum}

For identification of candidate genes responsible for resistance to $F$. oxysporum in flax, we searched for genes that were up- or down-regulated in resistant cultivars and $\mathrm{BC}_{2} \mathrm{~F}_{5}$ populations under $F$. oxysporum infection, but did not show a change in expression (or showed less change) in susceptible cultivars. The full results are presented in Additional file 1 and the results for the top 30 differentially expressed genes (excluding two unknown genes) are presented in Table 6. 
Table 6 Genes that were specifically changed in resistant genotypes of flax in response to Fusarium oxysporum infection

\begin{tabular}{|c|c|c|c|c|}
\hline Blast symbol & Blast name & $\log _{2} F C$ & $p$-value & $F D R$ \\
\hline$S R G 1$ & Protein SRG1 & 5.2 & $1.0 \mathrm{E}-12$ & $2.5 \mathrm{E}-08$ \\
\hline U73C3 & UDP-glycosyltransferase 73C3 & 3.8 & $5.5 \mathrm{E}-11$ & $6.1 \mathrm{E}-07$ \\
\hline $\begin{array}{l}\text { AATP5; } \\
\text { AATPA; } \\
\text { ASD }\end{array}$ & $\begin{array}{l}\text { AAA-ATPase ASD, mitochondrial } \\
\text { AAA-ATPase At3g28510 } \\
\text { AAA-ATPase At3g28600 }\end{array}$ & 2.5 & 7.7E-11 & $6.1 \mathrm{E}-07$ \\
\hline HSP7C & Heat shock 70 kDa protein 3 & -2.1 & $1.9 \mathrm{E}-10$ & $9.6 \mathrm{E}-07$ \\
\hline HSP72 & Heat shock cognate $70 \mathrm{kDa}$ protein 2 & -1.9 & $2.0 \mathrm{E}-10$ & $9.6 \mathrm{E}-07$ \\
\hline$E 13 B$ & Glucan endo-1,3-beta-glucosidase & 4.1 & 2.6E-10 & $1.0 \mathrm{E}-06$ \\
\hline $\begin{array}{l}\text { HFA2D; } \\
\text { HFA7B }\end{array}$ & $\begin{array}{l}\text { Heat stress transcription factor } \mathrm{A}-2 \mathrm{~d} \\
\text { Heat stress transcription factor } \mathrm{A}-7 \mathrm{~b}\end{array}$ & -1.9 & 1.6E-09 & $4.8 \mathrm{E}-06$ \\
\hline EP1G & Epidermis-specific secreted glycoprotein EP1 & 2.2 & 2.0E-09 & $5.1 \mathrm{E}-06$ \\
\hline $\begin{array}{l}\text { CA4; } \\
\text { CB24 }\end{array}$ & $\begin{array}{l}\text { Chlorophyll a-b binding protein } 4, \\
\text { chloroplastic Chlorophyll a-b binding protein } \\
\text { P4, chloroplastic }\end{array}$ & -2.6 & 2.3E-09 & $5.1 \mathrm{E}-06$ \\
\hline EXLB1 & Expansin-like B1 & 2.7 & 2.4E-09 & $5.1 \mathrm{E}-06$ \\
\hline COL5 & Zinc finger protein CONSTANS-LIKE 5 & -2.8 & 2.7E-09 & $5.2 \mathrm{E}-06$ \\
\hline TIP12 & Probable aquaporin TIP1-2 & -3.3 & 3.8E-09 & $6.9 \mathrm{E}-06$ \\
\hline $\begin{array}{l}\text { HIP3; } \\
\text { HIP6 }\end{array}$ & $\begin{array}{l}\text { Heavy metal-associated isoprenylated } \\
\text { plant protein } 3 \text { Heavy metal-associated } \\
\text { isoprenylated plant protein } 6\end{array}$ & 1.8 & $7.2 \mathrm{E}-09$ & $1.2 \mathrm{E}-05$ \\
\hline GPAT1 & Glycerol-3-phosphate acyltransferase 1 & 2.5 & 8.3E-09 & $1.3 \mathrm{E}-05$ \\
\hline $\begin{array}{l}\text { MYB36; } \\
\text { MYB87 }\end{array}$ & $\begin{array}{l}\text { Transcription factor MYB36 } \\
\text { Transcription factor MYB87 }\end{array}$ & 1.8 & $1.0 \mathrm{E}-08$ & $1.5 \mathrm{E}-05$ \\
\hline $\mathrm{ACCH} 1$ & $\begin{array}{l}\text { 1-aminocyclopropane-1-carboxylate } \\
\text { oxidase homolog } 1\end{array}$ & 2.1 & 1.3E-08 & $1.9 \mathrm{E}-05$ \\
\hline AGL62 & Agamous-like MADS-box protein AGL62 & 4.3 & 3.2E-08 & 4.2E-05 \\
\hline TNG2 & Transport and Golgi organization 2 homolog & 1.8 & 4.6E-08 & $5.8 \mathrm{E}-05$ \\
\hline HSP83 & Heat shock protein 83 & -1.5 & 5.3E-08 & $6.3 \mathrm{E}-05$ \\
\hline GDPD1 & $\begin{array}{l}\text { Glycerophosphodiester phosphodiesterase } \\
\text { GDPD1, chloroplastic }\end{array}$ & 2.5 & 5.6E-08 & $6.3 \mathrm{E}-05$ \\
\hline $\begin{array}{l}\text { SAU32; } \\
\text { SAU72 }\end{array}$ & $\begin{array}{l}\text { Auxin-responsive protein SAUR32 } \\
\text { Auxin-responsive protein SAUR72 }\end{array}$ & 1.7 & $7.2 \mathrm{E}-08$ & $7.5 \mathrm{E}-05$ \\
\hline KSB & Ent-kaur-16-ene synthase, chloroplastic & 3.3 & 7.3E-08 & $7.5 \mathrm{E}-05$ \\
\hline $\begin{array}{l}\text { ERD10; } \\
\text { ERD14 }\end{array}$ & $\begin{array}{l}\text { Dehydrin ERD } 10 \\
\text { Dehydrin ERD14 }\end{array}$ & -2.4 & 8.7E-08 & $8.6 \mathrm{E}-05$ \\
\hline RFS & Galactinol-sucrose galactosyltransferase & -2.0 & $1.1 \mathrm{E}-07$ & $1.0 \mathrm{E}-04$ \\
\hline NAS4 & Probable nicotianamine synthase 4 & -2.3 & 1.1E-07 & $1.0 \mathrm{E}-04$ \\
\hline $\begin{array}{l}\mathrm{C} 82 \mathrm{C} 2 \\
\mathrm{C} 82 \mathrm{C} 4\end{array}$ & $\begin{array}{l}\text { Cytochrome P450 82C2 } \\
\text { Cytochrome P450 82C4 }\end{array}$ & 2.7 & $1.6 \mathrm{E}-07$ & $1.4 \mathrm{E}-04$ \\
\hline $\begin{array}{l}\text { IQD31; } \\
\text { STR15 }\end{array}$ & $\begin{array}{l}\text { Protein IQ-DOMAIN 31; } \\
\text { Rhodanese-like domain-containing protein } \\
\text { 15, chloroplastic }\end{array}$ & 2.6 & 1.7E-07 & $1.4 \mathrm{E}-04$ \\
\hline UGT8 & 7-deoxyloganetic acid glucosyltransferase & 2.3 & 2.0E-07 & $1.5 \mathrm{E}-04$ \\
\hline
\end{tabular}

Note: $F C$ - the ratio of average counts per million (CPM) in resistant genotypes under $F$. oxysporum infection to the average CPM in resistant genotypes under control conditions. FDR - false detection rate

Upregulation was revealed for genes encoding SRG1 (senescence-related gene 1) protein, UDP-glycosyltransferase 73C3 (UGT73C3), AAA-ATPase ASD, mitochondrial (AATPA), glucan endo-1,3-beta-glucosidase, MYB transcription factors, ERD dehydrins, and Auxin- responsive protein SAUR, among others. We suggest that the identified genes with specifically induced expression in response to $F$. oxysporum infection in resistant cultivars and resistant $\mathrm{BC}_{2} \mathrm{~F}_{5}$ populations are the most promising resistance gene candidates. 


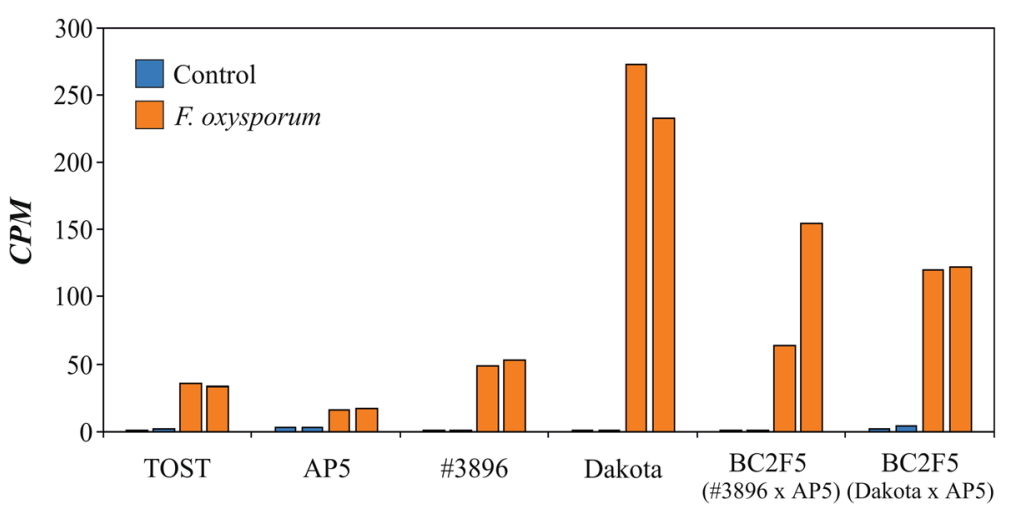

Fig. 1 Expression levels of the beta-1-3-glucanase gene in flax genotypes resistant (Dakota, \#3896, $B_{2} F_{5} \# 3896 \times A P 5, B C_{2} F_{5}$ Dakota $\left.\times A P 5\right)$ and susceptible (AP5 and TOST) to Fusarium wilt under control conditions and F. oxysporum infection. High-throughput sequencing data. CPM - count per million. Two biological replicates (10-12 plants in each) are represented for each condition

GO terms with the most significant differences between flax genotypes resistant and susceptible to the fungus, and the expression profiles of related genes are presented in Additional file 2. In resistant cultivars and populations, genes involved in the response to biotic stimulus and stress, defense response, antioxidant activity, and cell wall organization or biogenesis were more strongly upregulated than in the susceptible cultivars.

\section{Discussion}

Plant mechanisms of response to Fusarium infection include synthesis of PR proteins and antimicrobial compounds, production of ROS, and changes in cell wall structure [41-45]. In the present study, we evaluated the changes in gene expression in response to $F$. oxysporum infection in resistant and susceptible flax cultivars and resistant $\mathrm{BC}_{2} \mathrm{~F}_{5}$ populations. The advantage of our study is the use of the two $\mathrm{BC}_{2} \mathrm{~F}_{5}$ populations, which were obtained from crosses between the examined resistant and susceptible cultivars, and which are resistant to $F$. oxysporum but phenotypically similar to the susceptible parent. This approach allowed us to compare the changes in gene expression under $F$. oxysporum infection in resistant and susceptible genotypes and to identify genes that were specifically induced in resistant flax plants in response to the infection.

Significant downregulation of genes involved in cell wall organization or biogenesis was detected in response to F. oxysporum in susceptible cultivars (AP5 and TOST). However, we observed no similar trend in resistant cultivars and populations. It could be suggested that, in susceptible cultivars, changes in apoplast structure in response to $F$. oxysporum are more pronounced. The role of cell wall compounds in the response of flax [26, 46] and other plant species [47-49] to F. oxysporum has been revealed previously. However, the present study is the first to identify the differential expression of genes related to cell wall organization or biogenesis in flax cultivars and $\mathrm{BC}_{2} \mathrm{~F}_{5}$ populations with different resistance to Fusarium wilt.

A number of the top 100 upregulated genes in resistant cultivars are related to $\mathrm{NAD}(\mathrm{P}) \mathrm{H}$ oxidase activity. In susceptible cultivars, we also revealed upregulation of $\mathrm{NAD}(\mathrm{P}) \mathrm{H}$ oxidase-related genes; however, most of these were not included in the top 100 upregulated genes. $\mathrm{NAD}(\mathrm{P}) \mathrm{H}$ oxidases are involved in ROS signaling and stress response in plants, and are one of the sources of ROS that are induced in response to pathogen attack and involved in early defense responses via an oxidative burst [45, 50-57]. NADPH oxidase upregulation and early oxidative burst have been revealed in a resistant banana cultivar in response to $F$. oxysporum infection $[56,58,59]$. In flax plants, we observed a similar trend. ROS signaling associated with $\mathrm{NAD}(\mathrm{P}) \mathrm{H}$ oxidases could be one of the mechanisms constituting the L. usitatissimum defense response to $F$. oxysporum. We accordingly suggest that $\mathrm{NAD}(\mathrm{P}) \mathrm{H}$ oxidases could be promising candidates for proteins that participate in the defense response against $F$. oxysporum in flax.

The genes that were induced more strongly in the resistant genotypes of flax compared with the susceptible genotypes in response to $F$. oxysporum infection are involved in crucial biological processes, including transcription regulation, auxin signaling, stress response, and photosynthesis. The most significant upregulation was observed for genes encoding SRG1 protein, UGT73C3, AATP5, glucan endo-1,3-beta-glucosidase (beta-1-3-glucanase), and epidermis-specific secreted glycoprotein EP1. Among these proteins, beta-1-3-glucanase is the most well-known fungal-responsive protein in flax. This enzyme hydrolyzes beta-1,3-glucans of the cell wall in fungi, and the role of this protein in plant defense against pathogens is well known [60-64]. In flax, increased resistance to $F$. oxysporum and F. culmorum has been observed in transgenic 
flax lines containing the potato beta-1,3-glucanase gene, and in plants overexpressing the beta-1,3-glucanase gene $[18,19]$. We also revealed the upregulation of this gene in flax plants in response to $F$. oxysporum infection, and the changes were observed to be stronger in the cultivars and $\mathrm{BC}_{2} \mathrm{~F}_{5}$ populations showing resistance to Fusarium wilt (Fig. 1). In resistant genotypes under F. oxysporum infection, the induction of beta-1,3-glucanase expression was more pronounced compared with that in susceptible genotypes ( $p<0.01$, Mann-Whitney test). Moreover, under the stress conditions, the expression level of beta-1,3-glucanase was significantly higher in resistant cultivars and populations $(p<0.05)$, whereas under control conditions, there was no significant difference between the resistant and susceptible genotypes.

Thus, in response to $F$. oxysporum infection, we revealed changes in the expression of genes that encode PR proteins, and also in genes that are involved in ROS production and cell wall structure change. Furthermore, we identified genes that were specifically upregulated in flax genotypes resistant to Fusarium wilt. Special attention should be given to these genes in further searches for resistance gene candidates. Our work complements previously obtained results on flax response to $F$. oxysporum infection and provides a basis for detailed investigations of flax defense mechanisms against Fusarium wilt.

\section{Conclusions}

In the present study, we used high-throughput sequencing to search for genes involved in the early defense response of $L$. usitatissimum against infection by the fungus $F$. oxysporum. To this end, we first used resistant and susceptible flax cultivars and $F$. oxysporum-resistant $\mathrm{BC}_{2} \mathrm{~F}_{5}$ populations, which were obtained from crosses between the resistant and susceptible flax cultivars. An analysis of gene expression revealed diverse patterns of differentially expressed genes for resistant and susceptible flax genotypes. Genes involved in response to biotic stimulus and stress, defense response, antioxidant activity, and cell wall organization or biogenesis were more strongly upregulated in the resistant genotypes than in the susceptible genotypes. Moreover, we identified genes that were specifically induced in genotypes resistant to Fusarium wilt in response to $F$. oxysporum infection. These genes are the most promising candidates for genes conferring resistance to $F$. oxysporum infection in L. usitatissimum.

\section{Additional files}

Additional file 1: Genes for which expression was specifically changed in resistant genotypes of flax in response to Fusarium oxysporum infection. (XLSX $9584 \mathrm{~kb})$
Additional file 2: Expression profiles of genes for selected gene ontology (GO) terms in susceptible and resistant flax genotypes in response to Fusarium oxysporum infection. (XLSX $861 \mathrm{~kb}$ )

\section{Acknowledgments}

The authors thank All-Russian Research Institute for Flax for the selection and provision of flax seeds and $F$. oxysporum isolate. This work was performed using the equipment of "Genome" center of Engelhardt Institute of Molecular Biology (http://www.eimb.ru/rus/ckp/ccu_genome_c.php).

\section{Funding}

This work was financially supported by the Russian Science Foundation, grant 16-16-00114. Publication costs were funded by the Russian Science Foundation, grant 16-16-00114.

\section{Availability of data and materials}

The datasets generated during the current study are available in the Sequence Read Archive - SRP119227.

\section{About this supplement}

This article has been published as part of BMC Plant Biology Volume 17 Supplement 2, 2017: Selected articles from Belyaev Conference 2017: plant biology. The full contents of the supplement are available online at https:// bmcplantbiol.biomedcentral.com/articles/supplements/volume-17supplement-2.

\section{Authors' contributions}

$A D$, TR, and NM conceived and designed the work; TR, RN, AS, MF, OY, NB, and NM performed the experiments; AD, GK, OM, NB, AK, and NM analyzed the data; $A D, G K$, and NM wrote the manuscript. All authors read and approved the final manuscript.

Ethics approval and consent to participate

Not applicable.

\section{Consent for publication}

Not applicable.

\section{Competing interests}

The authors declare that they have no competing interests.

\section{Publisher's Note}

Springer Nature remains neutral with regard to jurisdictional claims in published maps and institutional affiliations.

\section{Author details}

'Engelhardt Institute of Molecular Biology, Russian Academy of Sciences, Moscow, Russia. ${ }^{2}$ All-Russian Research Institute for Flax, Torzhok, Russia.

Published: 28 December 2017

\section{References}

1. Marchenkov A, Rozhmina T, Uschapovsky I, Muir AD. Cultivation of flax. In: Muir AD, Westcott ND, editors. Flax: the genus Linum. New Yorek: Taylor \& Francis; 2003. p. 74-91.

2. Galindo-Gonzalez L, Mhiri C, Grandbastien MA, Deyholos MK. Ty1-copia elements reveal diverse insertion sites linked to polymorphisms among flax (Linum Usitatissimum L.) accessions. BMC Genomics. 2016;17(1):1002.

3. Bolsheva NL, Zelenin AV, Nosova IV, Amosova AV, Samatadze TE, Yurkevich OY, et al. The diversity of karyotypes and genomes within section Syllinum of the genus Linum (Linaceae) revealed by molecular cytogenetic markers and RAPD analysis. PLoS One. 2015;10(4):e0122015.

4. Kumar S, You FM, Duguid S, Booker H, Rowland G, Cloutier S. QTL for fatty acid composition and yield in linseed (Linum Usitatissimum L.). TAG Theoretical and applied genetics Theoretische und angewandte Genetik. 2015;128(5):965-84.

5. Soto-Cerda BJ, Diederichsen A, Duguid S, Booker H, Rowland G, Cloutier S. The potential of pale flax as a source of useful genetic variation for cultivated flax revealed through molecular diversity and association analyses. Mol Breed. 2014;34(4):2091-107. 
6. Melnikova NV, Kudryavtseva AV, Zelenin AV, Lakunina VA, Yurkevich OY, Speranskaya AS, et al. Retrotransposon-based molecular markers for analysis of genetic diversity within the genus Linum. Biomed Res Int. 2014;2014:231589.

7. Choudhary SB, Sharma HK, Kumar AA, Maruthi RT, Mitra J, Chowdhury I, et al. SSR and morphological trait based population structure analysis of 130 diverse flax (Linum Usitatissimum L.) accessions. Comptes rendus biologies. 2017;340(2):65-75.

8. Dash PK, Cao Y, Jailani AK, Gupta P, Venglat P, Xiang D, et al. Genome-wide analysis of drought induced gene expression changes in flax (Linum Usitatissimum). GM crops \& food. 2014;5(2):106-19.

9. Yu Y, Huang W, Chen $H, W u$ G, Yuan H, Song $X$, et al. Identification of differentially expressed genes in flax (Linum Usitatissimum L.) under salinealkaline stress by digital gene expression. Gene. 2014;549(1):113-22.

10. Yu Y, Wu G, Yuan H, Cheng L, Zhao D, Huang W, et al. Identification and characterization of miRNAs and targets in flax (Linum Usitatissimum) under saline, alkaline, and saline-alkaline stresses. BMC Plant Biol. 2016;16(1):124.

11. Dmitriev AA, Kudryavtseva AV, Krasnov GS, Koroban NV, Speranskaya AS, Krinitsina AA, et al. Gene expression profiling of flax (Linum Usitatissimum L. ) under edaphic stress. BMC Plant Biol. 2016;16(Suppl 3):927.

12. Dmitriev AA, Kudryavtseva AV, Bolsheva NL, Zyablitsin AV, Rozhmina TA, Kishlyan NV, et al. miR319, miR390, and miR393 are involved in aluminum response in flax (Linum Usitatissimum L.). Biomed Res Int. 2017;2017:4975146.

13. Dmitriev AA, Krasnov GS, Rozhmina TA, Kishlyan NV, Zyablitsin AV, Sadritdinova AF, et al. Glutathione S-transferases and UDPglycosyltransferases are involved in response to aluminum stress in flax. Front Plant Sci. 2016;7:1920.

14. Rashid KY. Principal diseases of flax. In: Muir AD, Westcott ND, editors. Flax: The genus Linum. Boca Raton: CRC Press; 2003. p. 92-123.

15. Diederichsen A, Rozhmina TA, Kudrjavceva LP. Variation patterns within 153 flax (Linum Usitatissimum L.) genebank accessions based on evaluation for resistance to fusarium wilt, anthracnose and pasmo. Plant Genetic Resources: Characterization and Utilization. 2008;6(1):22-32.

16. Spielmeyer W, Green AG, Bittisnich D, Mendham N, Lagudah ES. Identification of quantitative trait loci contributing to Fusarium wilt resistance on an AFLP linkage map of flax (Linum Usitatissimum). TAG Theoretical and applied genetics Theoretische und angewandte Genetik. 1998;97:633-41.

17. Galindo-Gonzalez L, Deyholos MK. RNA-seq Transcriptome response of flax (Linum Usitatissimum L.) to the pathogenic fungus Fusarium oxysporum $\mathrm{f}$. Sp. lini. Front Plant Sci. 2016;7:1766

18. Wrobel-Kwiatkowska M, Lorenc-Kukula K, Starzycki M, Oszmianski J, Kepczynska E, Szopa J. Expression of beta-1,3-glucanase in flax causes increased resistance to fungi. Physiol Mol Plant P. 2004;65(5):245-56.

19. Wojtasik W, Kulma A, Boba A, Szopa J. Oligonucleotide treatment causes flax beta-glucanase up-regulation via changes in gene-body methylation. BMC Plant Biol. 2014:14:261.

20. Wojtasik W, Kulma A, Dyminska L, Hanuza J, Zebrowski J, Szopa J. Fibres from flax overproducing beta-1,3-glucanase show increased accumulation of pectin and phenolics and thus higher antioxidant capacity. BMC Biotechnol. 2013;13:10.

21. Lorenc-Kukula K, Wrobel-Kwiatkowska M, Starzycki M, Szopa J. Engineering flax with increased flavonoid content and thus Fusarium resistance. Physio Mol Plant P. 2007;70(1-3):38-48.

22. Lorenc-Kukula K, Zuk M, Kulma A, Czemplik M, Kostyn K, Skala J, et al. Engineering flax with the GT family 1 Solanum Sogarandinum Glycosyltransferase SsGT1 confers increased resistance to Fusarium infection. J Agric Food Chem. 2009;57(15):6698-705.

23. Boba A, Kulma A, Kostyn K, Starzycki M, Starzycka E, Szopa J. The influence of carotenoid biosynthesis modification on the Fusarium culmorum and Fusarium oxysporum resistance in flax. Physiol Mol Plant P. 2011:76(1):39-47.

24. Hano C, Addi M, Fliniaux O, Bensaddek L, Duverger E, Mesnard F, et al. Molecular characterization of cell death induced by a compatible interaction between Fusarium oxysporum f. Sp. linii and flax (Linum Usitatissimum) cells. Plant Physiol Biochem. 2008;46(5-6):590-600.

25. Zeitoun AM, Preisner M, Kulma A, Dyminska L, Hanuza J, Starzycki M, et al. Does biopolymers composition in seeds contribute to the flax resistance against the Fusarium infection? Biotechnol Prog. 2014;30(5):992-1004.

26. Wojtasik W, Kulma A, Kostyn K, Szopa J. The changes in pectin metabolism in flax infected with Fusarium. Plant Physiol Biochem. 2011;49(8):862-72.
27. Kostyn K, Czemplik M, Kulma A, Bortniczuk M, Skala J, Szopa J. Genes of phenylpropanoid pathway are activated in early response to Fusarium attack in flax plants. Plant Sci. 2012;190:103-15.

28. Boba A, Kostyn K, Kostyn A, Wojtasik W, Dziadas M, Preisner M, et al. Methyl Salicylate level increase in flax after Fusarium oxysporum infection is associated with Phenylpropanoid pathway activation. Front Plant Sci. 2016;7:1951.

29. Wojtasik W, Kulma A, Namysl K, Preisner M, Szopa J. Polyamine metabolism in flax in response to treatment with pathogenic and non-pathogenic Fusarium strains. Front Plant Sci. 2015;6:291.

30. Kroes GMLW, Baayen RP, Lange W. Histology of root rot of flax seedlings (Linum Usitatissimum) infected by Fusarium oxysporum f.Sp. lini. Eur J Plant Pathol. 1998;104(7):725-36.

31. Bolger AM, Lohse M, Usadel B. Trimmomatic: a flexible trimmer for Illumina sequence data. Bioinformatics. 2014;30(15):2114-20.

32. Grabherr MG, Haas BJ, Yassour M, Levin JZ, Thompson DA, Amit I, et al. Fulllength transcriptome assembly from RNA-Seq data without a reference genome. Nat Biotechnol. 2011:29(7):644-52.

33. Simão FA, Waterhouse RM, loannidis P, Kriventseva EV, Zdobnov EM. BUSCO: assessing genome assembly and annotation completeness with single-copy orthologs. Bioinformatics. 2015;31(19):3210-2.

34. Haas BJ, Papanicolaou A, Yassour M, Grabherr M, Blood PD, Bowden J, et al. De novo transcript sequence reconstruction from RNA-seq using the trinity platform for reference generation and analysis. Nat Protoc. 2013;8(8):1494-512.

35. Finn RD, Clements J, Arndt W, Miller BL, Wheeler TJ, Schreiber F, et al. HMMER web server: 2015 update. Nucleic Acids Res. 2015;43(W1):W30-8.

36. Punta M, Coggill PC, Eberhardt RY, Mistry J, Tate J, Boursnell C, et al. The Pfam protein families database. Nucleic Acids Res. 2012;40(Database issue):D290-301.

37. Langmead B, Salzberg SL. Fast gapped-read alignment with bowtie 2. Nat Methods. 2012;9(4):357-9.

38. Li B, Dewey CN. RSEML: accurate transcript quantification from RNA-Seq data with or without a reference genome. BMC bioinformatics. 2011;12:323.

39. Robinson MD, McCarthy DJ, Smyth GK. edgeR: a bioconductor package for differential expression analysis of digital gene expression data. Bioinformatics. 2010;26(1):139-40.

40. Young MD, Wakefield MJ, Smyth GK, Oshlack A. Gene ontology analysis for RNA-seq: accounting for selection bias. Genome Biology. 2010;11, p. R14. doi: 10.1186/gb-2010-11-2-r14.

41. Chen YC, Kidd BN, Carvalhais LC, Schenk PM. Molecular defense responses in roots and the rhizosphere against Fusarium oxysporum. Plant Signal Behav. 2014;9(12):e977710

42. Berrocal-Lobo M, Molina A. Arabidopsis defense response against Fusarium oxysporum. Trends Plant Sci. 2008;13(3):145-50.

43. Slavokhotova AA, Shelenkov AA, Korostyleva TV, Rogozhin EA, Melnikova NV, Kudryavtseva AV, et al. Defense peptide repertoire of Stellaria Media predicted by high throughput next generation sequencing. Biochimie. 2017;135:15-27.

44. Chen YC, Wong CL, Muzzi F, Vlaardingerbroek I, Kidd BN, Schenk PM. Root defense analysis against Fusarium oxysporum reveals new regulators to confer resistance. Sci Rep. 2014:4:5584.

45. Swarupa V, Ravishankar KV, Rekha A. Plant defense response against Fusarium oxysporum and strategies to develop tolerant genotypes in banana. Planta. 2014;239(4):735-51.

46. Wojtasik W, Kulma A, Dyminska L, Hanuza J, Czemplik M, Szopa J. Evaluation of the significance of cell wall polymers in flax infected with a pathogenic strain of Fusarium oxysporum. BMC Plant Biol. 2016:16:75.

47. VDB N, Berger DK, Hein I, Birch PR, Wingfield MJ, Viljoen A. Tolerance in banana to Fusarium wilt is associated with early up-regulation of cell wallstrengthening genes in the roots. Mol Plant Pathol. 2007;8(3):333-41.

48. Lionetti V, Giancaspro A, Fabri E, Giove SL, Reem N, Zabotina OA, et al. Cell wall traits as potential resources to improve resistance of durum wheat against Fusarium graminearum. BMC Plant Biol. 2015;15:6.

49. de Farias Viegas Aquije GM, Zorzal PB, Buss DS, Ventura JA, Fernandes PM Fernandes AA. Cell wall alterations in the leaves of fusariosis-resistant and susceptible pineapple cultivars. Plant Cell Rep. 2010;29(10):1109-17.

50. Torres MA, Jones JD, Dangl JL. Reactive oxygen species signaling in response to pathogens. Plant Physiol. 2006;141(2):373-8.

51. Amirsadeghi S, Robson CA, Vanlerberghe GC. The role of the mitochondrion in plant responses to biotic stress. Physiol Plantarum. 2007;129(1):253-66.

52. Moller IM. PLANT MITOCHONDRIA AND OXIDATIVE STRESS: electron transport, NADPH turnover, and metabolism of reactive oxygen species. Annu Rev Plant Physiol Plant Mol Biol. 2001;52:561-91. 
53. Grabelnych Ol, Borovik OA, Tauson EL, Pobezhimova TP, Katyshev Al, Pavlovskaya NS, et al. Mitochondrial energy-dissipating systems (alternative oxidase, uncoupling proteins, and external NADH dehydrogenase) are involved in development of frost-resistance of winter wheat seedlings. Biochemistry. Biokhimiia. 2014;79(6):506-19.

54. Kamal AH, Komatsu S. Involvement of reactive oxygen species and mitochondrial proteins in biophoton emission in roots of soybean plants under flooding stress. J Proteome Res. 2015;14(5):2219-36.

55. Zhu QH, Stephen S, Kazan K, Jin G, Fan L, Taylor J, et al. Characterization of the defense transcriptome responsive to Fusarium oxysporum-infection in Arabidopsis using RNA-seq. Gene. 2013;512(2):259-66.

56. Li CY, Deng GM, Yang J, Viljoen A, Jin Y, Kuang RB, et al. Transcriptome profiling of resistant and susceptible Cavendish banana roots following inoculation with Fusarium oxysporum f. Sp. cubense tropical race 4. BMC Genomics. 2012;13:374.

57. Liu HY, Dai JR, Feng DR, Liu B, Wang HB, Wang JF. Characterization of a novel plantain Asr gene, MpAsr, that is regulated in response to infection of Fusarium oxysporum f. Sp. cubense and abiotic stresses. J Integr Plant Biol. 2010:52(3):315-23.

58. Dowd C, Wilson IW, MCFadden H. Gene expression profile changes in cotton root and hypocotyl tissues in response to infection with Fusarium oxysporum f. Sp. vasinfectum. Molecular plant-microbe interactions : MPMI. 2004;17(6):654-67.

59. Li WM, Qian CM, Mo YW, YL H, Xie JH. Tolerance of banana for fusarium wilt is associated with early $\mathrm{H} 2 \mathrm{O} 2$ accumulation in the roots. Afr J Biotechnol. 2011:10(55):11378-87.

60. Ward ER, Payne GB, Moyer MB, Williams SC, Dincher SS, Sharkey KC, et al. Differential regulation of beta-1,3-Glucanase messenger RNAs in response to pathogen infection. Plant Physiol. 1991;96(2):390-7.

61. Beffa R, Meins F Jr. Pathogenesis-related functions of plant beta-1,3-glucanases investigated by antisense transformation-a review. Gene. 1996;179(1):97-103.

62. Chang MM, Hadwiger LA, Horovitz D. Molecular characterization of a pea beta-1,3-glucanase induced by Fusarium solani and chitosan challenge. Plant Mol Biol. 1992;20(4):609-18.

63. Sanchez-Rangel D, Sanchez-Nieto S, Plasencia J. Fumonisin B1, a toxin produced by Fusarium verticillioides, modulates maize beta-1,3-glucanase activities involved in defense response. Planta. 2012;235(5):965-78

64. Balasubramanian V, Vashisht D, Cletus J, Sakthivel N. Plant beta-1,3-glucanases: their biological functions and transgenic expression against phytopathogenic fungi. Biotechnol Lett. 2012;34(11):1983-90. 